\title{
Port-Centered Transport DeVELOPMENT IN COLONIAL NORTH SUMATRA
}

\author{
Christopher Airriess
}

From the middle 1800s to World War Two, the northeast coast of Sumatra emerged as the most productive plantation district in the archipelago and indeed one of the most productive colonial plantation districts in the tropical world (Fig. 1). Supplying foreign markets with a variety of plantation products including rubber, oil palm, tea, coffee, tobacco, and Manila hemp, the region became known worldwide as Oostkust Cultuurgebeid or East Coast Plantation District. ${ }^{1}$ Over a seventy-year period there developed a system of estuarinesituated ports along a 350 kilometer mangrove-clothed coastline servicing this productive plantation region. As nodes linking land and maritime transportation, these ports functioned as points of economic exchange and articulation between this resource frontier region and the distant resource consuming regions of the industrialized world.

Throughout the colonial period, the port system of North Sumatra experienced structural changes in response to transformations in the regional plantation economy induced by the progressive maturation of industrial world economies. These structural changes were a result of developments originating from both the port hinterland and port foreland sides of the colonial transport surface. The respective elements of the port system have been described as "developed landspace and waterspace connected with a port by means of transport lines which ship and receive goods through that port." 2 The spatial configuration of hinterland and foreland links reveals much about the nature of production and trade upon which ports are sustained. The hinterland of a particular port is influenced by the nature and areal distribution of economic activity and supporting transport infrastructure allowing for exchange between the port and surrounding productive space. The configuration of port forelands is in turn influenced primarily by maritime transport technology and maritime trading networks. Because port development in colonial possessions is a transport response to a foreign-imposed and controlled economic structure, foreland factors assume primary

\footnotetext{
1 Thee Kian Wee, "Plantation Agriculture and Export Growth: An Economic History of East Sumatra, 1863-1942" (Ph.D. dissertation, University of Wisconsin, 1969); Karl Pelzer, Planter and Peasant: Colonial Policy and the Agrarian Struggle in East Sumatra 1863-1947 (The Hague: Nihoff, 1978).

2 Guido Weigand, "Some Aspects in the Study of Port Geography," Geographical Review 48 (1958): 185-200.
} 


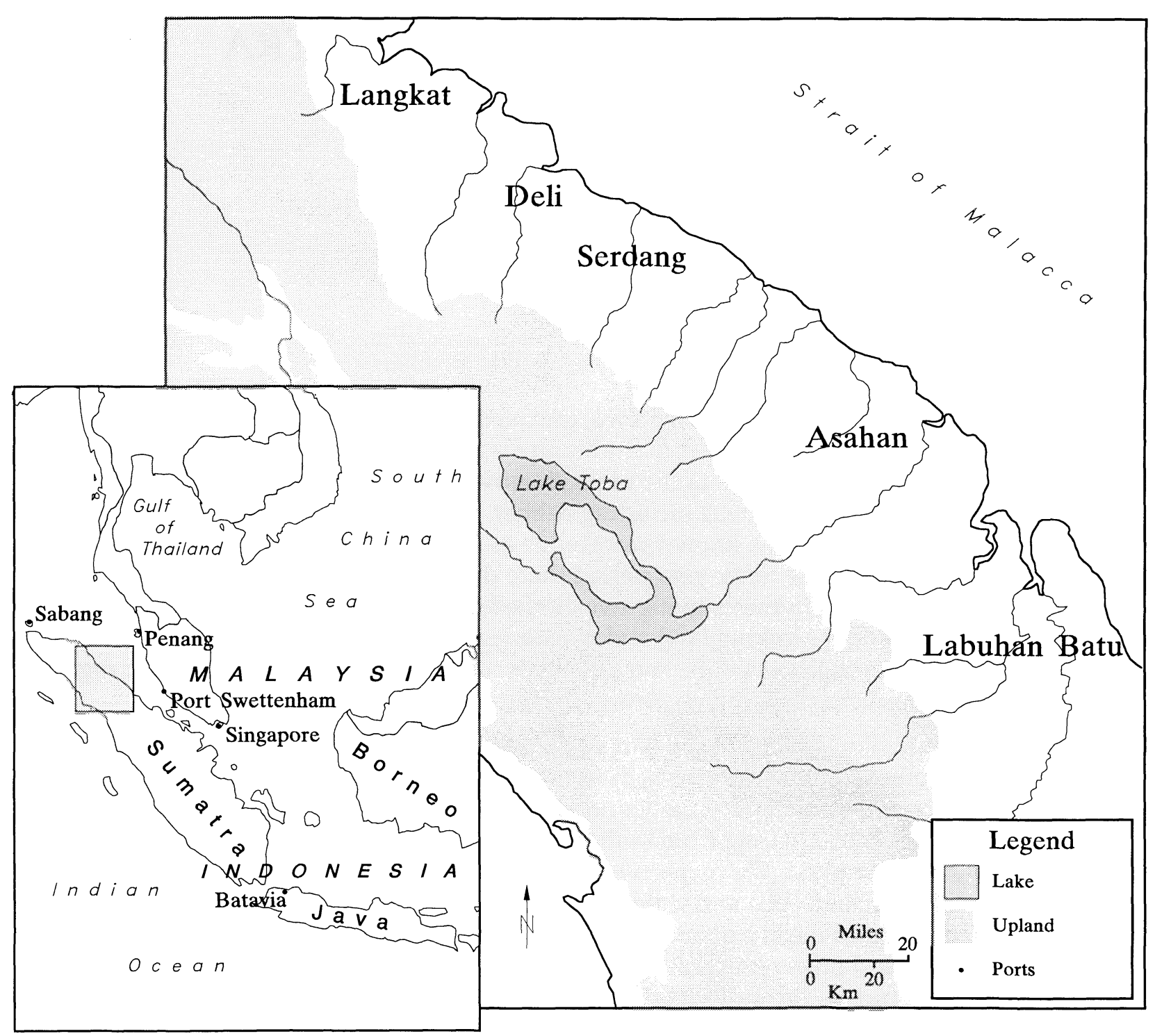

Fig. 1. Regions of North Sumatra and Locations of Extra-regional Ports Referred to in the Text. 
importance in giving shape to regional port system morphology. The third element of a port system are port facilities. Such facilities intimately reflect the spatial extent of hinterland and foreland connections, because port facilities, such as berths, transit sheds, cargo handling technologies, and industry, are material expressions of a port's transport connections at the regional and global scales.

The purpose of this paper is, first, to describe the morphological changes in the regional port-centered transport system of colonial North Sumatra. This description is accompanied by an analysis of the externally induced structural shifts in the regional economy that gave shape to the colonial transport system. Colonial port systems' development is divided into two time periods; the Pioneer Plantation Era (1870s-1910s) and the Florescence Plantation Era (1910s-1940s). Each period is marked by major structural changes in the regional economy and port system morphology induced by the differential spatial penetration of capitalist modes of production in North Sumatra. Documenting changes in the regional port system first requires a brief description of port hierarchy dynamics for each period, followed by a detailed examination of how port hinterlands, port forelands, and port facilities influenced port hierarchy dynamics. While the morphologies of hinterland, foreland, and port facility elements of the regional port system are in reality functionally interlinked, each is treated separately for organizational convenience.

There is a dearth of studies focusing upon transport development, and maritime transport in particular, during the late colonial period in Indonesia. With the exception of studies on perahu transport in Indonesia, ${ }^{3}$ interisland trade, ${ }^{4}$ and port morphology, ${ }^{5}$ late-colonial period historical research suffers from "land-mindedness." 6 This is surprising because Indonesia is "as naturally favored a region for maritime commerce as any in the world."7 More specifically, the historical aspects of North Sumatra's plantation economy have been thoroughly documented from the perspective of commodity production, ${ }^{8}$ agrarian policy, ${ }^{9}$ and labor. ${ }^{10}$ Little attention, however, has been accorded to the role of transport in the plantation economy, an often hidden, but crucial component of any production process. ${ }^{11}$

\footnotetext{
${ }^{3}$ Howard Dick, "Prahu Shipping in Eastern Indonesia," Bulletin of Indonesian Economic Studies 11, 2 and 3 (1975): 69-107 and 81-103.

${ }^{4}$ Howard Dick, "Interisland Trade, Economic Integration, and the Emergence of the National Economy," in Indonesian Economic History in the Dutch Colonial Era, ed. Anne Booth, W. J. O'Malley, and Anna Weidemann (New Haven: Yale University Southeast Asian Studies, 1990), pp. 296-321; J.N.F.M a Campo, Koninklijk Paketvaart Maatschappij: Stoomvaart en Staatsvorming in de Indonesische Archipel 1888-1914 (Hilversum: Verloren, 1992).

${ }^{5}$ Christopher Airriess, "Global Economy and Port Morphology in Belawan, Indonesia," Geographical Review 81 (1991): 183-96.

${ }^{6}$ Donald Emmerson, "The Case for a Maritime Perspective on Southeast Asia," Journal of Southeast Asian Studies 11, 1 (1984): 139-45.

7 Anthony Reid, "The Pre-Colonial Economy of Indonesia," Bulletin of Indonesian Economic Studies 20, 2 (1984): $151-67$.

${ }^{8}$ Thee, Plantation Agriculture.

${ }^{9}$ Pelzer, Planter and Peasant.

${ }^{10}$ Ann Stoler, Capitalism and Confrontation in Sumatra's Plantation Belt (New Haven: Yale University Press, 1985); Jan Bremen, Taming the Coolie Beast: Plantation Society and the Colonial Order in Southeast Asia (New Delhi: Oxford, 1990).

11 David Harvey, "The Geography of Capitalist Accumulation: A Reconstruction of Marxian Theory," Antipode 7, 2 (1975): 9-21. For a discussion of how "spatial movement is part of [the] production process," see James Blaut, The Colonizer's Model of the World: Geographical Diffusionism and Eurocentric History (New York: Guildford Press, 1993), p. 169.
} 


\section{The Pioneer Plantation Era (1870s-1910s)}

When compared to other Southeast Asian coasts, port activity and trade in North Sumatra during the precolonial era remained negligible. From the twelfth to the fourteenth centuries, a Chinese trading quarter located just upstream from the present-day port of Belawan occasionally engaged in international commerce. ${ }^{12}$ In the sixteenth and seventeenth centuries when a far more competitive trade regime emerged in response to the early penetration of Europeans, port activity in North Sumatra increased. The region, however, never supported a single powerful native kingdom and was characterized by constant conflict among several feudal states. ${ }^{13}$ Products were thus exported through ports in southern Aceh, a powerful maritime kingdom to the immediate north. ${ }^{14}$ Even during the early nineteenth century, port activity remained stagnant because the Dutch focused their energies upon Java and the export of tropical produce under the "Culture System." With little surplus capital to sustain the Culture System ${ }^{15}$ and little motivation to assume the military and administrative costs of colonial control, the Dutch viewed the east coast of Northern Sumatra, as well as other outerisland regions of the archipelago, as the "lastposten" or nuisances of the Dutch Empire in the East Indies. ${ }^{16}$

In the absence of Dutch administrative and commercial interests during the first half of the nineteenth century, the British and their Chinese "comprador" surrogates from Penang and Singapore established commercial toeholds along the coast of North Sumatra, particularly at Deli and the Asahan port of Tanjung Balai. ${ }^{17}$ From the Straits Settlement "gateways"18 of Penang and Singapore, Chinese traders comprising the economic "intelligence complex"19 initiated the greater flow of imports and exports to and from North Sumatra. Natively grown pepper, in great demand worldwide, ${ }^{20}$ was the primary export, and a

12 Edward McKinnon and Tengku Lukman Sinar, "Notes on Further Developments at Kota Cina," Sumatra Research Bulletin, Hull University 4, 1 (1974): 63-86; John Miksic, "Traditional Sumatran Trade," Bulletin de l'Ecole Française D'Extrême-Orient 74 (1985): $423-67$.

13 John Anderson, Mission to the East Coast of Sumatra in 1823 (reprint: Kuala Lumpur: Oxford University Press, 1971); Anthony Milner, "The Malay Raja: A Study of Malay Political Culture in East Sumatra and the Malay Peninsula in the Early Nineteenth Century" (Ph.D dissertation, Cornell University, 1977).

14 Anthony Reid, "Trade and the Problem of Royal Power in Aceh: Three Stages: c. 1550-1700," in Pre-Colonial State Systems in Southeast Asia, ed. Anthony Reid and Lance Castles (Kuala Lumpur: Royal Asiatic Society, 1975), pp. 45-55.

${ }^{15}$ John Furnivall, Netherlands India: A Study of a Plural Economy (New York: Macmillan, 1944), p. 177.

${ }^{16}$ Ian Black, "The Lastposten: Eastern Kalimantan and the Dutch in the 19th and 20th Centuries," Journal of Southeast Asian Studies 15, 2 (1985): 281-91.

17 Tengku Lukman Sinar, "The Impact of Dutch Colonialism on the Malay Coastal States on the East Coast of Sumatra During the Nineteenth Century." Paper presented at the Dutch-Indonesian Historical Conference, Noordnijkerhout, the Netherlands, May 1976.

${ }^{18}$ For a discussion of gateway cities which are geographically positioned to monopolize the transport and marketing activities of hinterland production areas, see Andrew Burghardt, "A Hypothesis About Gateway Cities," Annals of the Association of American Geographers 61, 2 (1971): 269-85.

19 James Vance, The Merchant's World: The Geography of Wholesaling (Englewood Cliffs, N.J.: Prentice Hall, 1970), pp. 148-49.

${ }^{20}$ James Gould, "Sumatra-America's Pepperpot, 1784-1873," Essex Institute Historical Collections 92, 2 (1956): $83-152$. 
variety of British textiles, so crucial to the spread of a British capitalist economy, was the primary import. ${ }^{21}$

Only in the 1870s did North Sumatra become the focused target of foreign financial investment. Several factors explain the rush of foreign economic interests to the region. First, private interests in the Netherlands aggressively lobbied the mercantilist Dutch government to open North Sumatra to private interests, in part to challenge the growing British commercial presence in the region. Such lobbying efforts were successful with the enactment of the Agrarian Law in 1870 allowing for long-term land concessions to foreigners. Second, innovations in transport engineering were also crucial to the establishment of pioneering plantation culture in North Sumatra. The opening of the Suez Canal in 1869 reduced by half the sailing time of the "world peninsula" Cape of Good Hope journey and also greatly reduced the transport cost of transshipping goods across Egypt. ${ }^{22}$ Third, the replacement of sail by steam propulsion allowed for the cost efficient and regular carriage of maritime cargoes. ${ }^{23}$ Steamers were now able to make two to three trips per year as opposed to a single round trip so common under sail. In response, competition increased and freight rates were subsequently reduced on the Europe-Far East trade routes. ${ }^{24}$ This host of external developments now afforded North Sumatra the opportunity to trade plantation and other primary products on the global market.

While early European and Chinese trading interests were attracted to indigenously produced coconut, nutmeg, and coffee, it was cigar-wrapper tobacco leaf that signaled the systematic spatial penetration of small-scale planter culture. The rush of small-scale proprietary Dutch, Swiss, and German planters into the Deli region of North Sumatra was dramatic; in the early 1870s, twenty-two tobacco plantations were established, but by the mid-1890s, 120 plantations were in operation. ${ }^{25}$ Between 1870 and 1895, tobacco exports increased from 2,868 to 204,719 bales. ${ }^{26}$ Deli became a major source region for the expanding American cigar industry. By 1938, Deli cigar-wrapper tobacco leaf commanded almost four times the price of prestigious Cuban seed leaf and even greater value when compared to the same product from Java and the Philippines. ${ }^{27}$

The wealth created by the petty capitalist planter class rested upon the ruthless exploitation of labor. The clearing of virgin forest, the tracing of roads, the construction of rail lines, and the extremely labor-intensive system of planting, harvesting, and processing tobacco required huge labor inputs. Unable to obtain the needed numbers of workers from among local Malays and Bataks, as well as Javanese, planters recruited Chinese coolies; early source regions were the Straits Settlements, but by 1900 approximately 80 percent of the 87,938 plantation coolies came from southern China which during the 1890 s was experiencing serious economic hardship. ${ }^{28}$ Before arriving in North Sumatra, the coolies were in a

\footnotetext{
21 John Anderson, Acheen and Ports on the North and East Coasts of Sumatra (reprint: Kuala Lumpur: Oxford University Press, 1971).

22 George Boggars, "The Effect of the Opening of the Suez Canal on the Trade and Development of Singapore," Royal Asiatic Society, Malayan Branch 28, 1 (1955): 99-143.

23 Peter Hugill, World Trade Since 1431: Geography, Technology and Capitalism (Baltimore: Johns Hopkins University Press, 1993).

24 E. Fayle, A Short History of the World's Shipping Industry (London: Allen and Unwin, 1933), p. 233.

25 Pelzer, Planter and Peasant, p. 22.

${ }^{26}$ T. Volker, De la Forêt Vierge à un Teritoire de Culture Prospère (Medan: Association of Deli Planters, 1928), p. 18.

27 Thee, Plantation Agriculture, p. 19.

${ }^{28}$ Bremen, Taming the Coolie Beast, p. 57.
} 
sense pre-adapted to the regimented and dehumanizing work conditions of plantation life. Packed together on and below deck during their trip from China, inspected upon arrival in Belawan, and loaded onto freight cars like cattle for shipment to the plantation, laborers were "degraded effectively to resemble a labor commodity, pure and simple." 29 Because indentured labor toiling under the pervasive and draconian penal sanctions of the Coolie Ordinance of 1880 was pervasive, the plantation region of East Sumatra became infamous in Indonesia and the rest of the plantation world as a place of endemic cruelty.

\section{Port Hierarchies}

Typical of expanding resource frontiers, port hierarchies during the Pioneer Era were characterized by the proliferation of ports engaged in foreign trade (Fig. 2). ${ }^{30}$ In 1877, the distribution of port activity was spatially polarized, either at the northern or southern ends of the province, but by the turn of the century, much of the central coast was filled in with small ports sustained by trade with the Straits Settlements. The lion's share of port activity, however, was concentrated in Belawan and the smaller northern ports, because it was here in Deli and Langkat that small-scale planter activity was centered. ${ }^{31}$ Only in the closing years of the 1890 s did Belawan briefly lose its dominant position within the port hierarchy, falling to below a 50 percent share of regional cargo volume. The numerous ports in the central and southern regions of the province reflected the fragmented nature of hinterland production, with small-scale production of native products generally marketed and transported by Chinese traders. Throughout the period, Tanjung Balai never surrendered its position as the primary port for the southern part of province, in part aided by the southward spread of pioneer planters during the closing years of the era.

\section{Port Hinterlands}

In response to the initial penetration of Western planter activity and greater foreign demand for tropical products, land transport during the Pioneer Era developed rapidly (Fig. 3). The initial development of port-hinterland transport serviced the tobacco plantations located in the far northern Deli region around the newly created provincial capital of Medan. The earliest tobacco plantations were located along streams dissecting the Deli region and feeding into the Deli River. Tobacco was transported by oxcart to the nearest drainage canal or to a point on the river, where it was loaded on sampan-like boats (Fig. 4). ${ }^{32}$ From there it was shipped downstream to a point where it could be transshipped to a larger seagoing vessel anchored at mid-stream at the port of Labuhan Deli. Transport downstream became no longer necessary when, in 1875, a road was traced along the Deli River between Labuhan Deli and Medan. ${ }^{33}$

\footnotetext{
29 Ibid., p. 133.

${ }^{30}$ Export data is compiled from Statistiek van den Handel, de Scheepvart en de In- En Uitvoerrechten NederlandschIndie (Batavia: Landsdrukkerij, 1877, 1887, 1897, 1907).

31 In 1891 at the height of the tobacco boom, 118 , or 70 percent, of the total tobacco plantations in the province were located in Deli, Serdang, and Langkat; see W.H.M Schadee, Geschiedenis van Sumatra's Oostkust, vol. 2 (Amsterdam: Oostkust van Sumatra Instituut, 1919), p. 186.

32 Volker, De La Forêt, p. 71.

33 Jacobus Weisfelt, Deli Spoorweg Maatschappij als Factor in de Economische Ontwikkeling van de Oostkust van Sumatra (Rotterdam: Bronder, 1972), p. 36.
} 


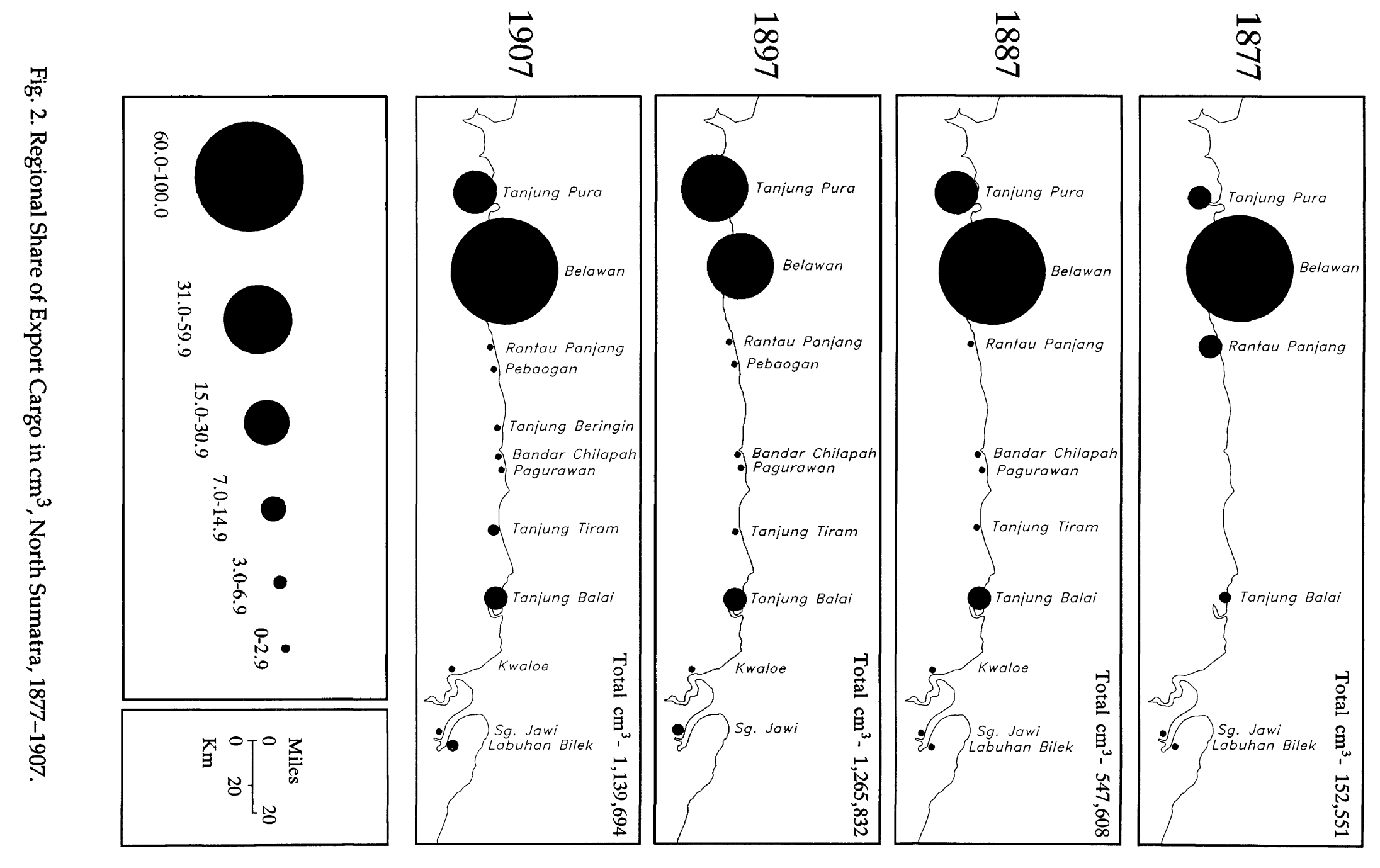




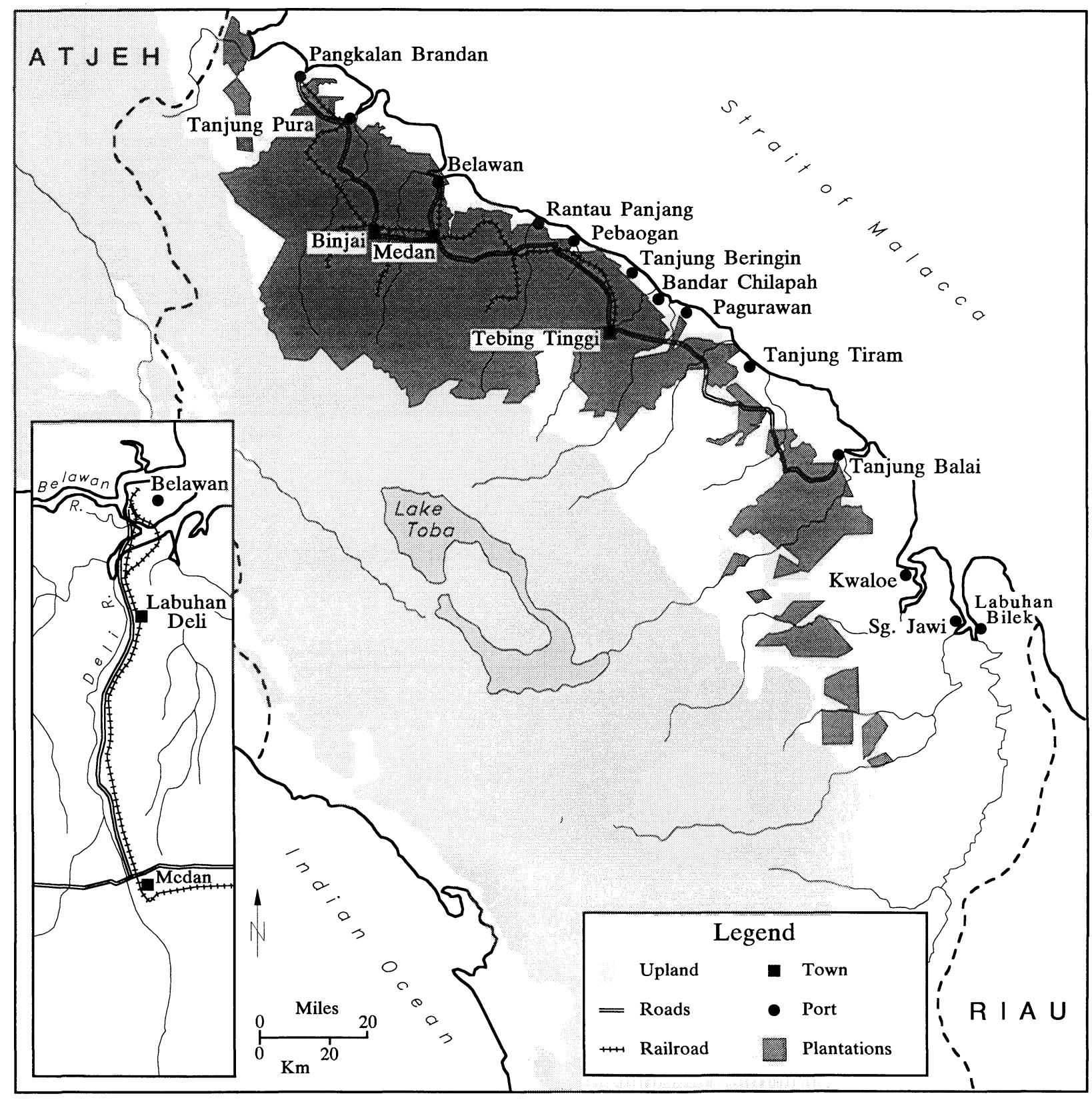

Fig. 3. Port-Hinterland Transport Links, North Sumatra, 1907. 


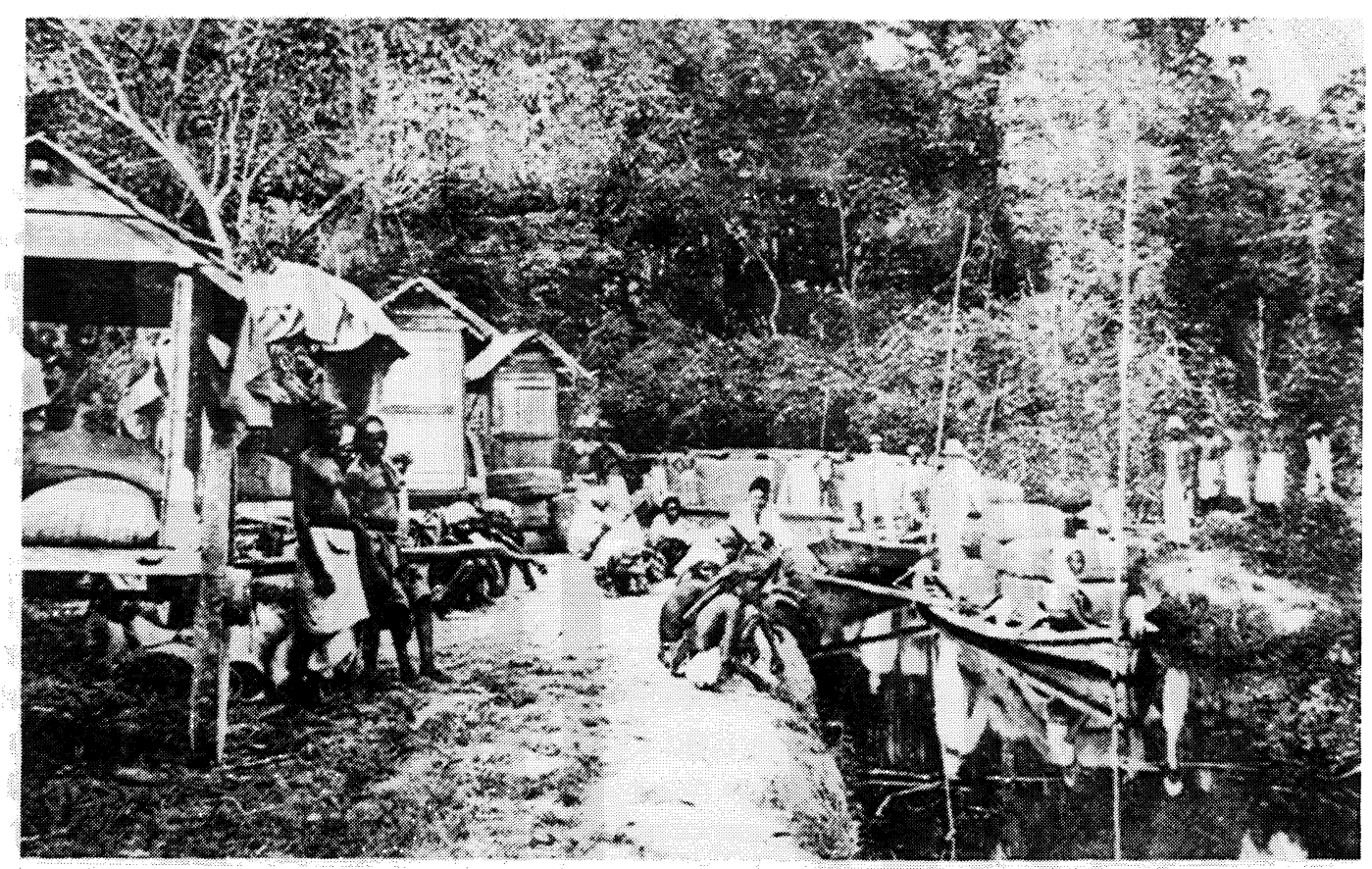

Fig. 4. A tobacco-laden sampan on a canal during the $1890 \mathrm{~s}$. Photo courtesy of Tengku Lukman Sinar.

Although plantations located on the periphery of Deli were connected to Labuhan Deli by inter-plantation roads, both distance and the poor conditions of roads, particularly during the wet monsoon, made road transport of tobacco logistically difficult. Despite these roads being described as "deep mudpools, partly filled with the remains of wrecked oxcarts," 34 the colonial government failed to respond positively to the planters' calls for better roads. Official neglect of transport infrastructure improvement was in part a government reaction to the arrogance of the individualistic and multinational plantocracy class who economically and socially gravitated toward the Malay Peninsula. ${ }^{35}$ The official government reason was that road maintenance was the responsibility of the native rulers, because it was they who held permanent title to the land. It was only in 1892 that the colonial government assumed responsibility for road construction and maintenance and then only for the primary arteries. ${ }^{36}$ Being located in different drainage basins then, these peripheral regions supported different riverine access. For example, as pioneer plantations to the near south in Serdang were not part of Labuhan Deli's hinterland, sole foreign access to them was through the downstream estuarine ports of Rantau Panjang and Pebaogan. ${ }^{37}$

With road transport in such poor condition, the spread of planter activity beyond the immediate Deli region was contingent upon the introduction of rail transport. Primarily financed by the Deli Maatschappij (the largest plantation concern and the first limited liability company in the Netherlands Indies), but planned by the newly formed Deli Planters

34 Deli in Woord en Beeld (Amsterdam: de Bussy, 1905), p. 6.

35 Bremen, Taming the Coolie Beast, p. 182.

36 Pelzer, Planter and Peasant, p. 40.

37 Deli in Woord, p. 5. 
Association, the Deli Spoorweg Maatschappij (DSM) or Deli Railway Company was established in 1883 as the only private rail company in the Outer Islands. Much like the other major rail lines in Java, the DSM lines were the "normal" gauge width of 1.067 meters. The first line was laid between Labuhan Deli and Medan replacing a road traced just a decade before. That same year, the line was extended to Belawan Island in response to the construction of a railport allowing the direct transfer of exports from railcars to vessels. This major technical advance resulted in greater levels of transport efficiency. The spread of tobacco planters into the adjoining districts to Langkat in the north and Serdang in the south prompted the construction of short distance spur lines by 1900 . Some of these lines were tramways with a narrower gauge width, and thus required the transfer of goods at a rail station where the tramway intersected the major line.

By 1904, the trunk rail line reached the emerging plantation service center of Tebing Tinggi in the south. A few years earlier, in 1896, a road had been traced from Tebing Tinggi to Tanjung Balai in the distant south. While the road-rail modal split was possible for exports exiting Belawan from the central and southern regions, there was no enlargement of Belawan's hinterland because the arduous road journey and the small volume of exports from the south made smaller nearby ports a more viable transport alternative. Without a sustained Western presence in the south, exports from these smaller ports consisted primarily of natively produced goods marketed by Chinese traders. Transport of hinterland produce to estuarine ports involved either narrow overland paths or, more likely, because of extensive lowland swamps from Tanjung Balai southward, downstream river transport.

\section{Port Facilities}

While it was the well-developed port hinterland links of Labuhan Deli that explain this port's apex position within the regional port hierarchy, port facilities there played an influential role as well. Until the mid-1880s, these port facilities resembled those at other regional ports; exports were tranferred to small steamers moored in midstream of the Deli River. ${ }^{38}$ However, as steam vessels with deeper draft became more common, export goods brought to Labuhan Deli by land had to be shuttled downstream to vessels moored in the deeper waters of the Deli-Belawan River estuary. ${ }^{39}$ The downstream transfer of cargo was necessary because the ever-increasing soil runoff resulting from upstream plantation forest clearing caused the Deli River to become progressively shallower. By the 1870s, steamers were unable to navigate upstream to Labuhan Deli. ${ }^{40}$

After the extension of the rail line from Labuhan Deli to Belawan Island, the DSM constructed a permanent "railway port" in 1887. Although the DSM port facilities were of simple construction, landing stages and warehouses provided for better coordination between land and sea transport modes (Fig. 5). By 1890, similar facilities for the government and four large shipping firms were in place. Because of these new, deeper-water facilities, Labuhan Deli reverted to a fishing village; in 1890 rail-transported imports and exports amounted to 15,000 tons, but by 1892 , tonnage had decreased to 3,000 tons, and this mostly consisted of "atap" materials for tobacco barns brought in from nearby coastal areas. 41

\footnotetext{
38 Weisfelt, Deli Spoorweg Maatschappij, p. 54.

${ }^{39}$ Volker, De La Forêt, p. 73.

${ }^{40}$ H. Blink, "Sumatra's Oostkust in Hare Opkomst en Ontwikkeling als Economische Gewest," Tijdschrift voor Economische Geographie 2 (1918): 55-156.

41 Wouter Cool, Belawan-Oceanhaven, 2 vols. (Batavia: Department der Burgerlijke Openbare Werken, Afdeeling Havenwezen, 1917), 1: 3.
} 


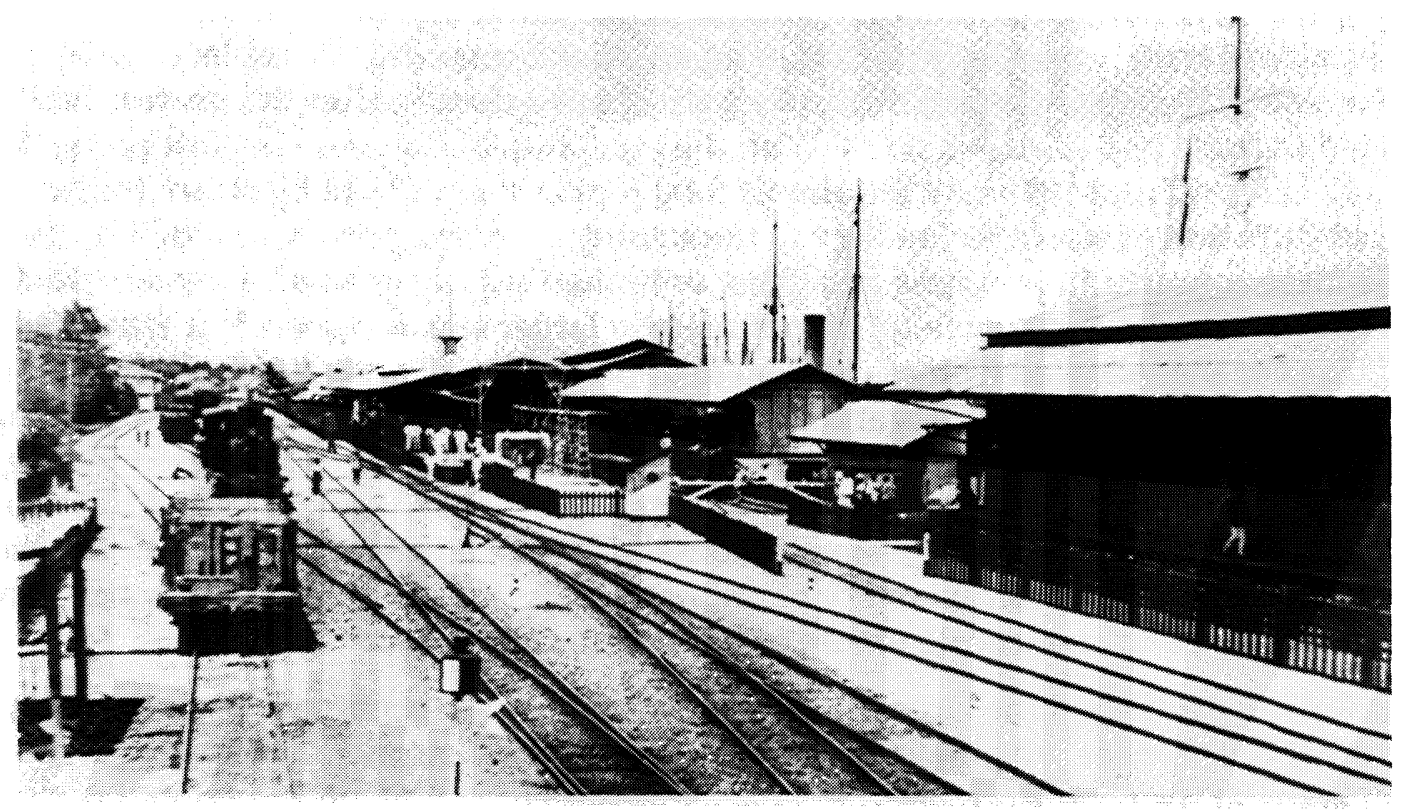

Fig. 5. The railport of Belawan during the early 1910s. Although allowing for the direct loading of goods between vessel and railcar, the facilities soon became inadequate, prompting the extension of the port emplacement. Photo courtesy of Tengku Lukman Sinar.

The new facilities immediately became inadequate for the efficient transfer of greater amounts of cargo. By 1907, the DSM extended the port emplacement. The almost doubling of landing and storage space was needed because of the increasing amount of trade; in 1888, the tonnage of goods carried by the DSM totaled 28,559 tons, but by 1900, this amount increased almost seven times to 185,775 tons. Part of this expansion included the construction of an "atap" harbor, which signaled the beginnings of the spatial segregation of modern from traditional or native technology. With atap being unloaded at Belawan, Labuhan Deli ceased all port functions.

Because of low levels of trade at other ports, the elaboration of their port facilities paled in comparison to those at Belawan. As the second busiest regional port, Tanjung Pura supported a handful of primitive landing stages and warehouses. Being the third busiest regional port, the far southern port of Tanjung Balai also developed a single landing stage to service both the handful of plantations and many native producers. Port facility development in Tanjung Balai did not keep pace with trade, however, as the single landing stage often caused delays if several large steam vessels called at the port at the same time. Because of insufficient berthing space, the landing stage was extended in 1908.42 The other smaller regional ports continued the precolonial practice of loading goods onto vessels moored midstream in the river.

The provisioning of port facilities and the type of vessels those facilities attracted also influenced port hierarchies, because the spatial spread of innovations in maritime transport is in part contingent upon the suitability of ports to accommodate new technologies. Steam

42 W. Knappert, "Memorie van Overgave Assistent Resident Asahan" (The Hague: Algemeen Rijksarchief [henceforth ARA], 1908), p. 5. 
transport replaced sail power at Belawan and Tanjung Pura, the first and second busiest ports respectively, during the Pioneer Era. In Belawan, more than 90 percent of total cargo throughput was transported in the holds of steamships. Steam did not replace sail at ports at the lower end of the regional port hierarchy until about a decade after the process had been completed in these two northern ports. With the exception of the four smallest ports, the years between 1887 and 1897 saw the almost total replacement of sail by steam transport. The rapid diffusion of steam technology to the smaller southern ports was aided by the ability of Chinese concerns to purchase an almost unlimited supply of small steamers from Western firms which were switching to increasingly larger steam vessels. ${ }^{43}$ It was this technology transfer that allowed Chinese traders to dominate small-scale maritime transport in many of the smaller southern ports and to usurp what was left of the indigenous trading class. In the mid 1890s, for example, seven Chinese-owned shipping firms based in Singapore and Penang operated nine steamships between North Sumatran ports and the two Straits Settlements. ${ }^{44}$ In some of the smaller southern ports, however, the relative absence of steam transport and continued viability of sailing vessels throughout the Pioneer Era attests to the fragmented and small-scale nature of hinterland production.

Belawan also attracted the largest steam vessels. The cargo capacity of vessels calling there during the Pioneer Era almost quadrupled. In most years, over the same period, steam vessels calling at the port had triple the capacity of vessels visiting other regional ports. While Western steamers frequently called at Tanjung Pura and Tanjung Balai, the greater size of those calling at Belawan was due to the greater economies of scale of both Western companies and port facilities. Because of limitations of cargo throughput, characteristic users of the ports at the lower end of the hierarchy were Chinese traders utilizing size appropriate steam technology.

While the elaboration of port facilities and resulting spread of steam transport allowed Belawan to command greater hinterland space, port-related industries there did not play a significant economic role. Its monopolization of export processing facilities would in principle have secured Belawan's dominant position in the regional port hierarchy, but the structure of plantation production did not engender port-related industries. Indeed, even in the hinterland, the only value-added processing prior to export was the curing of tobacco in barns and the stripping of waste vegetative matter from various plantation crops and forest produce. While Belawan as a break-of-bulk site would seem to provide a possible location for such activity, transport of bulky raw materials to the coast is generally not cost efficient, so simple processing facilities were located at the source of raw materials. ${ }^{45}$

\section{Port Forelands}

Because of superior hinterland connections and port facilities, Belawan (now also used to refer to Labuhan Deli) occupied the apex of the regional port system throughout much of the Pioneer Era. Belawan did not, however, monopolize regional port traffic. Its inability to

\footnotetext{
${ }^{43}$ Howard Dick, The Indonesian Interisland Shipping Industry (Singapore: Institute of Southeast Asian Studies, 1985), p. 4. The vessel tonnage difference between the principal Western corporate and Chinese "kongsi" shipping firms was substantial; in the early 1890s, European-owned vessels averaged 449 tons and Chineseowned vessels averaged 109 tons, see Schadee, Geschiedenis van Sumatra's, pp. $214-42$.

44 Schadee, Geschiedenis van Sumatra's, p. 242.

45 For an explanation of this weight-losing, minimum cost location theory, see Alfred Weber, Theory of the Location of Industries (Chicago: University of Chicago Press, 1929).
} 
usurp the trade of the smaller regional ports attests to the fact that port foreland morphology greatly influenced the structure of the regional port system.

Much like the situation in the early 1800s, the Malayan Straits Settlement ports of Penang and Singapore continued to possess a pivotal position in the provision of transport for North Sumatra. Throughout much of the Pioneer Era, 50 percent of North Sumatran cargo was transshipped via the Straits Settlements, particularly through Penang which entailed only a fourteen-hour journey when compared to forty-five hours for Singapore. The 50 percent figure increased to 75 percent beginning in 1899 after the commencement of a trans-Straits feeder service by the German firm Nederland Lloyd. ${ }^{46}$ This is why smaller ports, particularly Tanjung Pura, with seemingly close land connections to Belawan, remained viable; as long as goods were transshipped in the Straits Settlements, there was no need to transport goods over land through Belawan. The short distance transport connections between the smaller regional ports and the Straits Settlements were also guaranteed by business networks. Many Chinese within the hinterlands of smaller ports functioned as factors for Straits Settlement Chinese trading firms, thus cementing the trans-Straits transport link. The common use of the Straits dollar in North Sumatra up until the 1920s is evidence of this close economic relationship.

A similar situation existed among larger-scale, primarily European shipping firms. While ocean routes between Java and Europe were served by Dutch shipping firms, maritime access to North Sumatra, as well as to the rest of the archipelago, was basically controlled by foreign shipping firms based in the Straits Settlements; even the mails were carried by a British shipping concern. ${ }^{47}$ The strong participation of non-Dutch companies was made possible by the Dutch Shipping Law of 1850 which put foreign-flagged vessels on equal competitive footing with Dutch carriers. ${ }^{48}$ Although used to circumvent Straits Settlement ports, the government shipping firm Koninklijk Paketvaart Maatschappij (KPM), or Royal Packet Company, was forced to participate in the trans-Straits feeder service as well. In fact by 1907, KPM vessels controlled 23 percent of this short-distance trade. Both English and German shipping firms required these numerous feeder services to sustain viable mainline route operations between Asia and Europe. ${ }^{49}$ In fact, feeder vessels were commissioned especially for the tobacco trade, and a special relationship existed between planters in Deli and the principal English shipping company, Ocean Steamship Company..$^{50}$ The KPM operated a dedicated feeder service between North Sumatra and Batavia specifically for the tobacco trade, but after a few years the service was terminated because calls at intermediate ports caused spoilage and time-consuming delays. ${ }^{51}$

The proliferation and persistence of numerous smaller regional ports are a product of North Sumatra's transport tributary status, which might be described as "dentritic" because of the branching structure of the network; "all lower order centers [North Sumatran ports] are tied to a higher level center [Straits Settlements entrepôts] in a chain that is entirely vertical without horizontal links." The dentritic transport network label appropriately applies

\footnotetext{
${ }^{46}$ Deli en Woord, p. 17.

47 Dick, The Indonesian Interisland, p. 6.

48 Blink, Sumatra's Oostkust, pp. 69-70.

${ }^{49} \mathrm{~K}$. Trengonning, Home Port Singapore: A History of the Straits Steamship Company Limited (Singapore: Oxford University Press, 1967), p. 14.

${ }^{50}$ Francis Hyde, Blue Funnel: A History of the Alfred Holt and Company of Liverpool from 1865 to 1914 (Liverpool: Liverpool University Press, 1956), pp. 51, 83.

${ }^{51}$ Schadee, Geschiedenis van Sumatra's, p. 243.
} 
because dentritic systems "seem to occur mainly in colonial or recently colonial societies where marketing is not only imposed by conquest, but imposed by an outside group [Westerners or Straits Chinese] involved in the international market and import-export trade." 52 Direct colonial control through port investments and regulation would have produced a different regional port system hierarchy, because a greater amount of foreign maritime traffic would be concentrated on a fewer number of ports, particularly Belawan. The loss of direct control over trade and transport and the resulting fragmentation of regional port activity was, in fact, a manifestation of the inability of the Dutch colonial government to integrate the various regional economies of the archipelago into a single national economy. ${ }^{53}$

The approximately forty years marking the Pioneer Era in North Sumatra witnessed a dramatic structural transformation of the precolonial transport surface. The spatial development of hinterland and foreland transport surfaces and port facilities reflected the needs of a relatively small-scale Western plantation and Chinese trader class. During this frontier stage of capitalist penetration, hinterland links in the form of road and rail transport only benefited Belawan, as the limited investment capital of plantation concerns was spatially concentrated in the Deli region. It was only Belawan that supported sufficient traffic to warrant the provisioning of modern port facilities associated with the change from sail to steam propulsion and with the construction of a railway inland. The rapid proliferation of smaller ports in the south and the absence of inland connectivity with Belawan were products of the limited economic penetration of Western interests in the region and the parallel capturing of the southern ports by Chinese traders from the foreland gateways of the Straits Settlements. Beginning with the first decade of the twentieth century, however, the economic environment of North Sumatra would radically change with a more complete spatial penetration of foreign capital. The introduction of a wider variety of plantation crops, coupled with the growth of a more mature capitalist form of plantation production, set in place corresponding evolutionary responses in the regional port-centered transport system.

\section{Florescence Plantation Era (1910s-1940s)}

The thirty-year period between the 1910s and 1940s is described as being the "florescence" period of Western agricultural development in Indonesia and indeed much of the tropical world. This era witnessed the replacement of luxury with industrial plantation crops to feed the rapid expansion of a large-scale economy of the West. ${ }^{54}$ The appetite for raw materials in this new economies-of-scale production process initiated a far greater control of raw materials by distant Western countries. The transition from Pioneer to Florescence Eras involved a switch from the purchase and trade of plantation products to direct production, and from family to corporate control. ${ }^{55}$ As a result, foreign investment in North Sumatra "created a comprehensive agro-industrial structure probably unmatched for complexity, efficiency, and scale anywhere in the world."56

\footnotetext{
52 C. Smith, "Economics of Marketing Systems: Models from Economic Geography," Annual Review of Anthropology 3 (1974): 167-201.

53 Dick, Interisland Trade, p. 301.

54 William Wertheim, Indonesian Society in Transition (The Hague: van Hoeve, 1946), p. 96.

55 Julius Boeke, The Evolution of the Netherlands Indies Economy (New York: Institute of Pacific Relations, 1946), p. 13.

56 Clifford Geertz, Agricultural Involution (Berkeley: University of California Press, 1974), pp. 85-86.
} 
The tradition of planting expertise, favorable physical conditions, available land, and the open-door policy of the colonial government attracted corporate investment in planting rubber, oil palm, tea, and fibers. Trial rubber plantings in the 1890 s increased to 200,000 planted hectares by 1926, primarily by the American firms of Goodyear, Goodrich, and HollandschAmerikaansche Plantagen Maatschappij; the British concern Harrison Crossfields; and the French-Belgian concern Société Financière des Caoutchoucs. ${ }^{57}$ Responding to the rapidly expanding auto industry, ${ }^{58}$ North Sumatra accounted for 11 percent of world rubber production in 1932.59 Peasant or smallholder swidden cultivation accounted for 16 percent of provincial rubber acreage, much of which was spatially concentrated in the southern districts of Asahan and Labuhan Batu. ${ }^{60}$ By 1920, two other important estate crops gained prominence. The most important was oil palm, which by 1938 had made North Sumatra the largest single exporting region in the world. Tea, grown exclusively within the cooler confines of the Simalungun foothills around the town of Pematang Siantar, was also established. Unlike rubber, these latter two estate crops were grown exclusively on Westernowned plantations. ${ }^{61}$

These new estate crops allowed for the opening up of the undeveloped southern half of North Sumatra and the wholesale expansion of the regional economy and spatial spread of plantation activity beyond the pre-twentieth century core centered on Deli. What the emergence of this integrated agro-industrial plantation system meant for the transport sector was a rapid adjustment in both technology and spatial reach. Meeting the demands of the Florescence Era economy required a capital-intensive response in transport infrastructure to match the capitalization of the plantation economy, so that ports would not become the weak link in the total chain of the production process.

The growth of corporately controlled perennial estate production required a massive input of additional labor. Because of high recruiting and transport costs, and a newly imposed tax on imported labor, estate corporations turned to Java as a labor recruiting region. By 1930 , the estate labor force numbered approximately 336,000 , comprising 30 percent of East Sumatra's total population. The human condition changed little from the Pioneer Era: poor living conditions, depressed estate wages, widespread prostitution and accompanying sexually transmitted diseases, extremely high mortality rates, and physical abuse as a product of corporate labor strategies undermined the creation of a healthy and permanent workforce from one that was traditionally transitory. During the Depression almost half of the 1930 estate labor force was dismissed and many were repatriated to Java. Many of those who remained on estates were hired part-time, at reduced wages, and given small farm plots on the plantation periphery for food security. By 1940, 74 percent of estate laborers were locally recruited and many were family-based workers, allowing for the reproduction of a resident labor pool. ${ }^{62}$

\footnotetext{
57 Thee, Plantation Agriculture, pp. 24-28.

58 Austin Coates, The Commerce in Rubber (Singapore: Oxford University Press, 1987), pp. 137-41.

59 J. De Waard, "De Oostkust Van Sumatra," Tijdschrift voor Economische Geografie 25, 8 (1934): 263.

60 Pelzer, Planter and Peasant, p. 53.

61 Thee, Plantation Agriculture, pp. 57-64.

62 For an insightful and theoretically penetrating analysis of corporate estate labor control, see Stoler, Capitalism and Confrontation.
} 

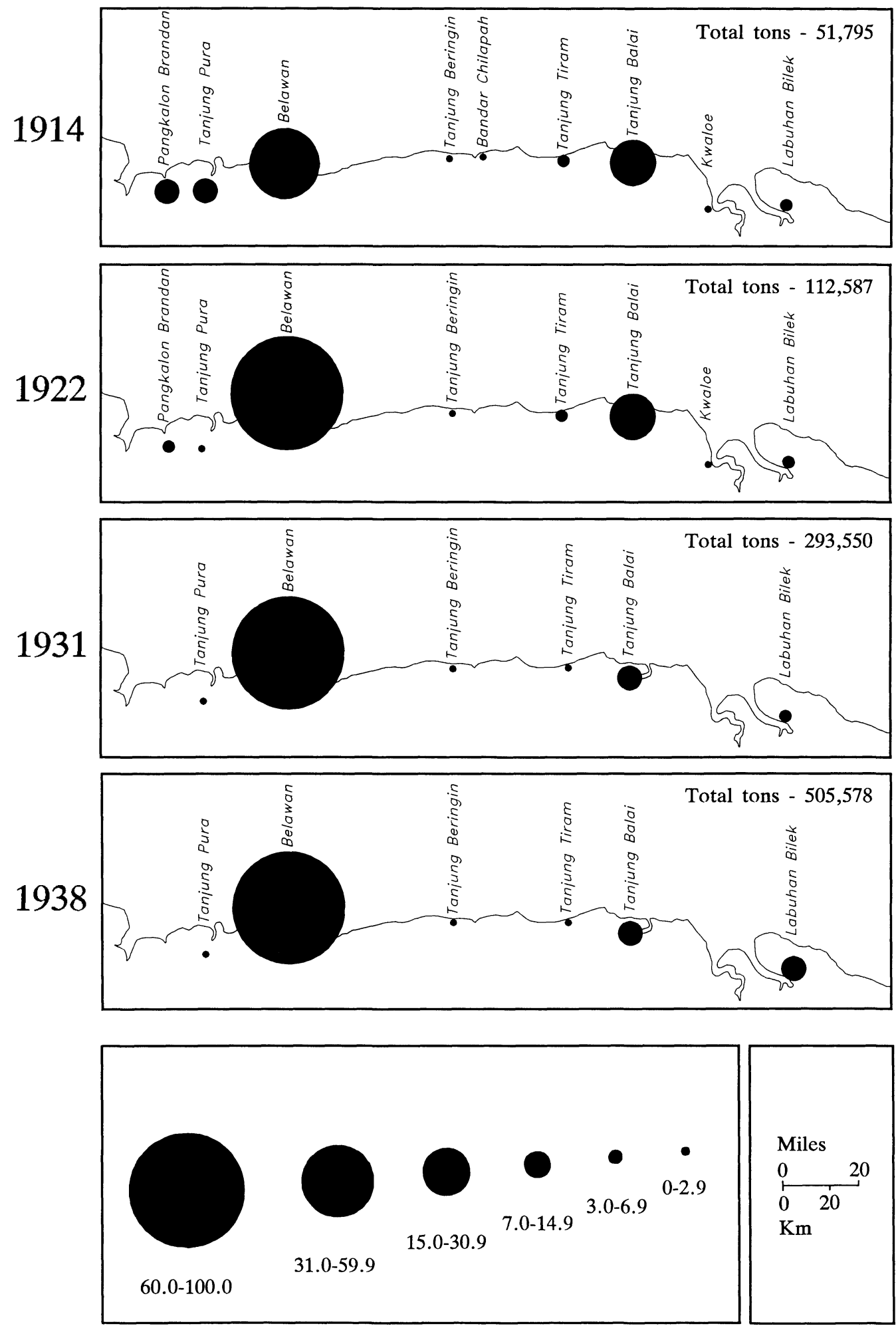

Fig. 6. Regional Share of Export Cargo in Tons, North Sumatra, 1914-1938. 


\section{Port Hierarchies}

The penetration of corporate plantation interests and the attendant increase in capital intensive production during the Florescence Era was paralleled by the concentration of foreign trade in a fewer number of ports (Fig. 6).63 Between 1907 and 1938, the number of ports engaged in foreign trade was halved from twelve to six. Belawan was the major beneficiary of the growth of the plantation-centered regional economy that witnessed an increase of cargo tons from 51,795 in 1914 to 505,578 in 1938. Between those same years, Belawan's regional share of cargo tonnage almost doubled from 45 to 80 percent. The increased primacy of the port was based on the dramatic spread in its road and rail hinterland, as well as an expanded foreland that now included direct and long-distance oceanic vessel calls. While Belawan captured much of Tanjung Balai's hinterland, this port continued and even strengthened its role, as did Labuhan Bilek, as an exit point for small-scale hinterland production in the southern regions of the province.

While the effects of the Great Depression significantly reduced world demand for plantation products, the approximately five years of economic contraction were not a sufficient catalyst to alter the structure of the pre-existing regional port hierarchy. Although the value of regional export surpluses declined from fl. 105.6 million in 1929 to 48.5 million in 1933, plantation product export volumes did not significantly decline. In the case of rubber and oil palm, long term production and export volume actually increased during the same period. Operating under conditions of high fixed costs, expansion of production in the mid-1920s, and inelasticity in terms of price and demand, plantations continued to produce and export despite decreased world demand. 64

\section{Port Hinterlands}

In response to the dramatic increase in the quantity and variety of plantation exports during the Florescence Era, hinterland transport development was dramatically transformed (Fig. 7). During the two-and-a-half decade period before World War Two, Belawan's hinterland rail connections increased by 279 kilometers, more than double the existing trackage, to reach a total of 404 kilometers. By 1915 the Tebing Tinggi to Tanjung Balai line was completed, and one year later a similar line was laid between Tebing Tinggi and the foothill town of Pematang Siantar to service the newly established tea and rubber estates. To the far south, Rantau Prapat was reached by rail in 1937. In the north, the Pangkalan Brandan line was extended to the Aceh border at Besitang in 1919, and in 1921 the Besitang to Pangkalan Susu line was completed. When compared to rail transport during the Pioneer Era, train speed on most tracks steadily increased from 45 to 65 kilometers per hour. ${ }^{65}$ In addition to a handful of similarly gauged secondary lines connecting some plantations to the trunk rail line, a second-tier rail infrastructure was also developed primarily by individual oil-palm plantations. Required to transport the bulky "bunches" to which the palm-oil fruit are attached, plantations were laced with very narrow gauged tracks connecting planted areas with the processing facility.

By the late 1920s most regions of North Sumatra were accessible to motor traffic. A major achievement was the completion of a major axial highway paralleling the coast which

\footnotetext{
63 Export data is compiled from Statistiek van den Handel, de Scheepvaart en de In-en Uitvoerrechten NederlandschIndie (Batavia: Landsdrukkerij, 1914, 1922, 1931, 1938).

64 Thee, Plantation Agriculture, pp. 38-39.

65 KRONIEK (Amsterdam, Oostkust van Sumatra-Instituut: de Bussy, 1922), p. 54.
} 


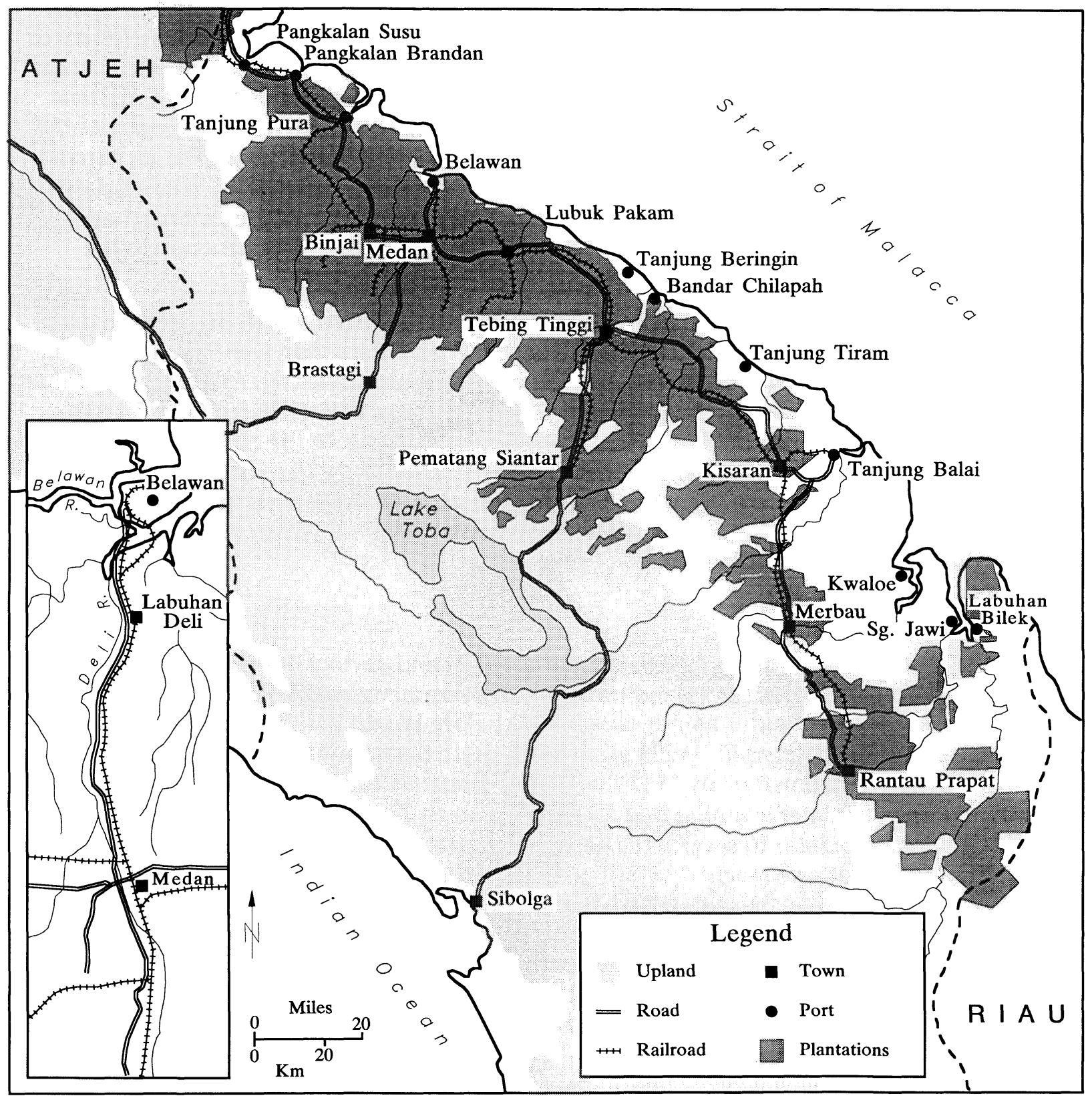

Fig. 7. Port-Hinterland Transport Links, North Sumatra, 1938. 
joined all the plantation districts, with the exception of Labuhan Batu in the far south; it was not until 1933 that Rantau Prapat became the southern terminus of this north-south highway. Two major lowland-highland highways were also in operation by the 1920s. The advent of truck transport along the major arteries and secondary roads by the early $1920 \mathrm{~s}$ posed serious competition to the DSM. Truck transport was more competitive because of greater route flexibility, but also because (unlike the situation in Java but similar to that in other frontier areas), there was little government regulation of road transport. In 1924 the DSM countered the flexibility of the ethnic Chinese-owned and operated trucking business by increasing the number of stations and trains, reducing tariffs, and introducing freightforwarding services. However, by the time road transport experienced systematic government regulation in 1933, a significant portion of the DSM's transport domain had been captured by truck. 66

To complement its function as the provincial government and plantation administrative center, Medan solidified its position as the region's dominant urban center by becoming a transportation center. Much like today, firms engaged in all manner of transport services did not locate their primary offices in Belawan, but in Medan. Within the matrix of the regional transport network, Medan also occupied a node where the two most heavily trafficked transport corridors converged; the lateral and north-south "mainstreet" paralleling the coast and the short east-west "high priority linkage" penetrating the interior from Belawan. ${ }^{67} \mathrm{~A}$ mirror image of transport development emerged across the Malacca Strait in the plantation districts of western Peninsular Malaya. As in North Sumatra, a mainstreet corridor paralleling the coast, and interior foothills joined the high priority linkage between the administrative and commercial capital of Kuala Lumpur and Port Swettenham.

Despite the extensive and enlarged interior hinterland of Belawan, however, some regions fell beyond the port's spatial reach. The first such region was south and west of Toba Lake. While some peasant-holder rubber and coffee from the highlands were transported to Belawan by road, ${ }^{68}$ the nearby west coast port of Sibolga provided a more convienent outlet. Exporting through Sibolga was facilitated by KPM vessels calling there, and a large fleet of native craft feeding goods south along the coast to the distant southwestern Sumatran port of Padang where ocean-going vessels called. 69

Belawan also possessed little hinterland pull in the direction of the lowland coastal tracts of Aceh to the north because few foreign-owned estates were established that allowed such a process to take place. The variety of native exports from a handful of ports were transported in the hulls of KPM vessels servicing the Aceh-Penang route. No all-weather roads linked Aceh with the northern terminus of the North Sumatran axial highway. Although occasionally promoted as an avenue linking Aceh with the DSM lines, and thus Belawan, the Aceh tramway never fulfilled this purpose for two primary reasons. First, because the Aceh tramway track gauge was 0.75 meters and the DSM track gauge was 1.067 meters, connections with Belawan meant the portaging of goods from one line terminus to the other at the provincial boundary. The second problem was that the Aceh tram was originally de-

\footnotetext{
66 Weisfelt, Deli Spoorweg Maatschappij, p. 99.

${ }^{67}$ For a discussion of an idealized description of transport development in the colonial world, see Edward Taaffe, Richard Morrill, and Peter Gould, "Transport Expansion in Underdeveloped Countries," Geographical Review 53 (1967): 503-29.

${ }^{68}$ E. Schroder, "Aanvullende Memorie van Overgave van het Gouvernement Oostkust van Sumatra," (ARA, 1920), p. 518.

${ }^{69}$ Schroder, "Aanvullende Memorie," p. 188.
} 
signed and maintained specifically for the purpose of transporting Dutch troops during the suppression of Aceh, and a change to commercial use of the tramway proved difficult.

Despite the rapid development of both large and small scale estates, and smallholder rubber production in the Labuhan Batu region, the hinterland pull of Belawan was weak in this southern region during the Florescence Era. First, the southern extension of the DSM line to Rantau Prapat never materialized until just before World War Two. Second, the 1920s was a period of rapid expansion of estate acreage, and the DSM was overextended with servicing customers in the central and northern regions of the province. In addition, attempts in the late 1920s to extend the line southward were hindered by the Great Depression; no physical expansion of services would have been financially prudent under conditions of economic contraction. The southern extension of rail tracks to the far northern Labuhan Batu town of Merbau, however, proved rewarding for the DSM; the Kwaloe and Merbau Rivers soon lost their transport function as the region fell within the hinterland of Belawan. ${ }^{70}$

Although the DSM line was extended further south to Rantau Prapat in 1937, Belawan's hinterland pull remained weak in this distant southern frontier. One reason was the historical momentum of riverine transport that had been in place for approximately twenty years which posed strong competition to the DSM. In 1924, a DSM annual report had stated that because freight rates were lowered to such an extent by the development of riverine transport to estuarine ports, the DSM was embarking upon no serious expansion in that direction. 71

In the absence of rail linkages, transport firms developed excellent connections between upriver locations and the principal port of Labuhan Bilek. The KPM serviced the Baroman River with paddle boats, which were later replaced by barges towed by motorboats ${ }^{72}$ that $^{2}$ transported the exports of seven plantation concerns. By 1937, the KPM operated a twice weekly lighter service between Labuhan Bilek and the nearby upstream town of Tanjung Pinang, a service encompassing the entire 100 kilometer length of the Baroman River. ${ }^{73}$ The KPM solidified its interests in the Labuhan Batu region by expanding into freight forwarding, replacing a number of Dutch firms servicing various plantation concerns. ${ }^{74}$ The use of rivers as avenues for exports was promoted by the provincial government and the Plantation Council, both of which saw to it that rivers were kept navigable. ${ }^{75}$

The development and continued use of riverine transport to ferry exports to Labuhan Bilek was also given impetus by the strong presence of Chinese traders in the Labuhan Batu region. Intermodal transport by river, by asphalted road, and then to the railhead at Merbau and later Rantau Prapat seemed too costly and inefficient when compared to riverine transport. ${ }^{76}$ As with Tanjung Balai, Labuhan Bilek was in a forward position for shipments to Singapore; even if rail transport to Belawan was available, the user cost for most Chinese traders would have meant reduced profits and would have broken the chain of middlemen upon which the entire trading network rested. Indeed, in the late 1920s and early 1930s, the dominant role of ethnic Chinese in riverine transport is aptly described by Cator; "naviga-

\footnotetext{
${ }^{70}$ M. Boon, "Memorie van Overgave van de Onderafdeling Laboean Batu" (ARA, 1931), p. 4.

71 Weisfelt, Deli Spoorweg Maatschappij, p. 97.

72 H. Morison, "Memorie van Overgave van de Onderafdeling Laboehan Batu," (ARA, 1933), p. 59.

73 G. Forch, "Memorie van Overgave van de Onderafdeling Laboean Batu," (ARA, 1937), p. 6.

74 Boon, "Memorie van Overgave," pp. 4-5.

75 M. Brouwer, "Verolgmemorie van Overgave van de Onderafdeling Laboean Batu," (ARA, 1924), pp. 2-3.

76 Morison, "Memorie van Overgave," p. 8.
} 
tion of the more important rivers along the East Coast is practically the prerogative of Chinese merchants who run paddle-boats and the like."77

The persistent use of smaller ports by Chinese traders was aided by the fact that native production was very much restricted to riverine lowlands not served by the corporate-centered road and rail network. In addition to locational advantages, viability of smaller ports was also aided by the nature of hinterland production. The lion's share of small port traffic was comprised of smallholder rubber which was purchased, milled, and marketed by Chinese merchants. Severing production ties between smallholders and Chinese merchants, however, would have meant the demise of smaller ports; the purchasing, milling, and marketing of smallholder output by corporate plantations would have benefited the larger ports of Belawan, Tanjung Balai, and Tanjung Pura. Because of the perceived economic threat of the smallholder sector, the high moisture content and impurities of native rubber, and a very fragmented production source, interaction between the two sectors never materialized. ${ }^{78}$

\section{Port Facilities}

Just as during the Pioneer Era small-scale plantation agriculture developed and hinterland transport expanded at a quicker pace than port facility infrastructure, so too did this sequence occur during the Florescence Era. The 1907 extension of berthing space in Belawan had been rapidly filled in by 1920 with the landing stages and hangers of many trading and steamship companies. The hangars, even the larger and newer ones, often overflowed so that damage was commonplace for goods stored on the unsheltered apron. The problem of access caused by overcrowded conditions was further exacerbated by the initiation of auto and truck traffic between Medan and Belawan in 1915, because the rail shunting yard became a barrier to the interface between vehicles and storage space.

Port congestion was further exacerbated by worsening hydrological conditions caused by increased siltation. In 1905 the depth of the channel at low tide was 7.5 feet, and even at high tide only vessels drawing less than 12 feet had access to the berths. Dredging activity continued apace, but once it stopped, shallow conditions immediately returned. ${ }^{79}$ Plans were formulated to construct three berths to accommodate steamships with 16-foot drafts on the north side of Belawan Island where the river depth was greater. The existing monies, however, were used instead to continue dredging the Belawan channel. ${ }^{80}$ North Sumatran plantation interests were of the opinion that the government provided too little financial commitment for dredging operations. This lack of attention ultimately prevented ocean steamers from calling at Belawan, resulting in high costs for transshiping to Straits Settlement ports. A port consultant noted that the cost of a new ocean harbor, allowing oceangoing vessels to call there, would easily be covered by the savings in transshipment costs. ${ }^{81}$

Because of the growing inability of Belawan to attract ocean-going steamships, several government-sponsored proposals were considered for developing an ocean harbor with

\footnotetext{
77 W.L. Cator, The Economic Position of the Chinese in the Netherlands Indies (Chicago: University of Chicago Press, 1936), p. 244.

78 Colin Barlow and John Drabble, "Government and the Emerging Rubber Industries in Indonesia and Malaysia, 1900-40," in Indonesian Economic History in the Dutch Colonial Era, ed. Booth, O'Malley, and Weidemann, pp. 187-209.

79 Cool, Belawan-Oceanhaven, pp. 4-5.

80 Nederlandsch-Indische Havens (Batavia: Departement der Burgerlijke Openware Werken, 1920), p. 71.

81 Blink, Sumatra's Oostkust, p. 147.
} 
fewer technical obstacles than Belawan. The most popular proposal was the further development of Sabang, a free port with extensive ocean-going port facilities on the island of Weh, off the northern tip of Aceh. In fact, in 1905 the KPM launched a regular service of coastal steamers between the various ports of North Sumatra and Sabang. While Sabang did succeed in capturing some North Sumatran trade, certain barriers prevented any real degree of success. First, the cost of transshipping in Sabang when compared to Penang was higher because of the greater distances involved. Second, there was less incentive to use Sabang because transshipment was still required. Last, the historical inertia of Chinese transportmarketing ties in Penang and Singapore seriously deprived Sabang of its potential share of North Sumatran cargo.

Although two additional feasibility studies were carried out for new ocean harbors in southern Aceh where hydrologic conditions were superior, economic interests in Medan actively opposed any alternative ocean harbor site. The Deli Planters Association, the General Association of Rubber Planters, the DSM, the Medan Trading Association, and even the provincial governor lobbied the colonial government in Batavia to continue its support of Belawan. ${ }^{82}$ The primary argument revolved around the fact that the economic advantages of Belawan far outweighed any present and future technical problems. ${ }^{83}$

North Sumatran economic interests were at a loss to understand why, with the volume and expansion of trade at Belawan, the colonial government appeared uninterested in upgrading facilities there. In bolstering their claim for greater financial support, they used Port Swettenham on the Malay Peninsula as a comparable example. Located between Penang and Singapore and possessing roughly equal volume of cargo throughput as Belawan, Port Swettenham received far more support from the British than the Dutch colonial government provided Belawan. ${ }^{84}$ Indeed, the major ports of Java had received extensive infrastructural improvements a decade earlier, leaving Belawan as the only major international port in the archipelago lacking modern port facilities. The reasons for government indifference toward port investment in North Sumatra were twofold. First, despite being a substantial income earner for the colonial treasury, North Sumatra was an Outer Island province and never garnered government energies traditionally reserved for Java. Second, an opinion developed within the colonial government that, because private interests had provided for the needed transport infrastructure in the past, the cost of new port facilities might be borne in a similar fashion.

Nevertheless, the colonial government did finally propose a major port development program for Belawan. In 1921, the first portion of the ocean harbor was completed on the north side of Belawan Island, at an actual cost of more than 26 million guilders. ${ }^{85}$ Three cement berths were constructed of cement with large and expansive warehouse space. Each berth was operated by the three major Dutch shipping companies of KPM, Rotterdam Lloyd, and the Nederland Navigation Company. ${ }^{86}$ As the berths were monopolized by Dutch shipping concerns, foreign flag carriers, particularly British vessels, were forced to wait in the roads for available berthing space or be serviced in midstream by lighters. ${ }^{87}$

\footnotetext{
82 Cool, Belawan-Oceanhaven, p. 28.

83 Weisfelt, Deli Spoorweg Maatschappij, p. 55.

84 Blink, Sumatra's Oostkust, p. 147.

${ }^{85}$ J. De Waard, "De Oostkust van Sumatra," Tijdschrift voor Economische Geografie 25, 9 (1934): 298.

${ }^{86}$ S. Bouman, "Memorie van Overgave van de Resident van Deli en Serdang," (ARA, 1929), p. 17.

87 KRONIEK (Amsterdam, Oostkust van Sumatra Instituut: de Bussy, 1938), p. 53.
} 
By 1927, the second stage of the ocean harbor was completed, extending berthing space, and thus allowing all major shipping companies adequate berthing and storage space. ${ }^{88} \mathrm{By}$ 1931, seven large and deep draft ocean-going vessels were able to be served simultaneously. ${ }^{89}$ A second line of warehouses was also constructed, bringing the total sheltered storage space to 60,000 square meters, ${ }^{90}$ almost six times the storage area of the older harbor (Fig. 8).

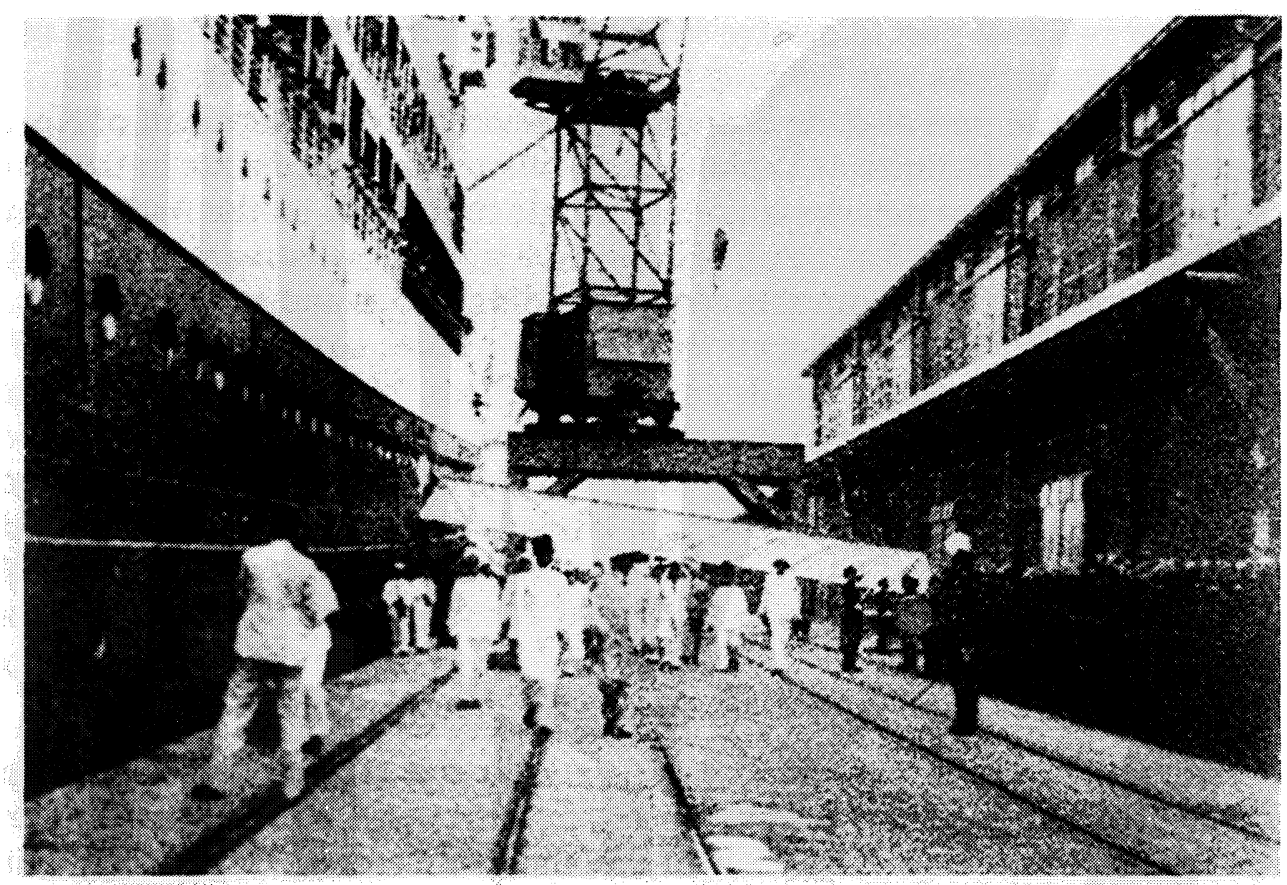

Fig. 8. A mailsteamer arriving at one of the wide apron berths of the oceanport during the 1930s. Source: H.V. Kohler, "Gids voor de Oostkust van Sumatra (Deli)" (Medan, 1939).

Specialized storage facilities were now required for the export of crude palm oil. Initially pumped into liquid bulk carriers from 600 kilogram drums, the loading rate only reached twelve tons per hour. Once additional modern storage tanks were in place, loading rates jumped to 200 tons per hour. ${ }^{91}$ Developed and used on a cooperative basis, oil-palm estates utilized eighteen oil-palm storage tanks with a capacity of $10,000 \mathrm{~m}^{3}$. By 1938 , the number of oil-palm storage tanks increased to fifty-two. ${ }^{92}$ The dramatic increase in world demand for rubber latex after the Depression years prompted the construction of four additional storage tanks. ${ }^{93}$

88 KRONIEK (Amsterdam, Oostkust van Sumatra Instituut: de Bussy, 1927), p. 64.

${ }^{89}$ KRONIEK (Amsterdam, Oostkust van Sumatra Instituut: de Bussy, 1931), p. 131.

${ }^{90}$ L. Sandick, "Aanvullende Memorie van Overgave van het Gouvernement Oostkust van Sumatra" (ARA, 1930), p. 128.

91 De Waard, De Oostkust, no. 8, p. 269.

92 KRONIEK (1938), p. 145.

93 Sandick, Aanvullende Memorie, p. 128. 
Just as the railway port replaced the midstream lighterage port of Labuhan Deli during the Pioneer Era, the modern ocean harbor replaced the older railway port during the Florescence Era. What emerged then were two functionally different areas of Belawan; the older railway port was relegated to functioning as a "coastal port," reserved for small-scale and technologically unsophisticated trans-Straits and Asian trade vessels, and the ocean harbor, servicing the needs of the capital intensive corporate plantation sector. ${ }^{94}$ The two port areas were simply transport responses to different scales of investment and hinterland production. 95

The only other regional port to receive substantial government investment in response to changed economic conditions was Tanjung Balai, which had solidified its position as the second busiest provincial port and the busiest port serving the southern half of North Sumatra. The evolution of port facilities at Tanjung Balai mirrors developments in Belawan, albeit on a smaller scale. Because of deteriorating hydrologic conditions on the Asahan River, a new port was completed in 1918 at Telok Nibung, five miles downstream from Tanjung Balai. The facilities included two durable cement landing stages and warehouses. In the same year, the DSM completed a rail spur from Tanjung Balai, so that, in the case of exports, goods could be loaded straight from railcars to warehouses. ${ }^{96}$ The Asahan region could now be effectively served by larger foreign vessels feeding cargo to Penang and Singapore. With the obvious exception of Belawan, Tanjung Balai was the only regional port to attract enough trade to warrant the spatial segregation of plantation and natively produced exports. It was described as being "a strange mixture between a European port like Belawan and ports exporting mainly native products such as Tanjung Pura and Tanjung Tiram."97 No other infrastructural developments took place at other ports; most trade goods continued to be handled between lighters and cargo vessels in mid-stream. ${ }^{98}$

The construction of a new ocean harbor in Belawan set in motion the diffusion and reception of new maritime transport technologies benefiting some ports and not others. Just as steam replaced sail power during the Pioneer Era, the 1920s witnessed the spread of diesel motor technology and the eventual replacement of steam vessels. By the late 1930s, motor vessels had diffused to the higher order regional ports, but never spread to the lower order ports where cargos continued to be transported in the hulls of steam and sailing vessels. Because of Belawan's new port facilities, the diesel motor vessels calling there were five to ten sizes larger than those calling at the second and third largest ports of Tanjung Balai and Tanjung Pura. Motor vessel technology did not diffuse down to the lowest order regional ports.

The improvement of port facilities at the busiest regional ports during the boom years of the mid-1920s was sufficient for them to handle the volume of exports during the Great Depression and the balance of the 1930s. In Belawan, for example, the size of the vessels calling there gradually decreased as large shipping firms found it less profitable to make frequent calls at the port because of the dramatic Depression-induced decline in import cargos. At the same time, the number of vessels increased as traders sought less expensive forms of trans-

\footnotetext{
94 For a theoretical discussion of the distinction between the lower "unincorporated" and higher "corporate" circuits of economic production, see M. Santos, The Shared Space (London: Methuen, 1979).

95 Airriess, "Global Economy," p. 190.

96 M. Hammerster, Bijdrage tot de Kennis van de Afdeeling Asahan (Amsterdam: Oostkust van Sumatra-Instituut, 1926), p. 202.

97 Jaarverslag van de Handelswereeniging te Medan (Medan: Varekamp and Company, 1918), p. 76.

98 Hammerster, Bijdrage tot de Kennis, p. 203.
} 
port during this time of economic contraction. Less is known about the smaller ports, but it can be assumed that a similar decrease in vessel size was common during this period. ${ }^{99}$

Although the Florescence Era witnessed a quantum increase in both the volume and variety of exports, no port-related industrial development emerged to provide certain ports with the opportunity to increase their respective hinterlands' reach. Ports continued their earlier Pioneer Era function as simple transfer and storage points between land and maritime transport media. Even in Belawan, all exports had been reduced in weight at processing facilities near the source of the raw materials before being transported to the coast. Western enterprise sought only to process plantation crops to a level affording portability overseas. Few production linkages emerged, then, between Belawan and its hinterland. In fact, the few trade and related service activities associated with hinterland production moved from the Pioneer Era ports to emerging north-south axial highway towns in the interior; from north to south, Tanjung Pura to Binjai, from Belawan to Medan, from Tanjung Beringin and Bandar Chilapah to Tebing Tinggi, from Tanjung Balai to Kisaran, and from Labuhan Bilek to Rantau Prapat. ${ }^{100}$

\section{Port Forelands}

With an expanding transport network funneling trade into Belawan and the construction of modern port facilities to secure calls by ocean-going steam vessels, it is not surprising that throughout the Florescence Era, trade became increasingly concentrated in Belawan. This concentration was a result of corporate plantation interests focusing upon this port because of the numerous long-distance foreland connections afforded here. By 1937, Belawan was the regular port of call for thirteen different foreign steamship companies, ${ }^{101}$ some of which participated in the newly formed Deli Freight Conference. ${ }^{102}$ Increased calls by ocean-going vessels at Belawan meant less transshipment in Straits Settlement ports by virtue of Belawan being one port of call on a multi-itinerary voyage; between 1932 and 1938 alone, the percentage of exports from Belawan being transshipped in the Straits Settlements decreased approximately 7 percent.

The nature of some export crops required direct shipment to Western consumers and this benefited Belawan as well. Tea and coffee, for example, required shipping directly to the industrialized world because of the perishability of the product. Time-consuming transshipment in the Straits Settlements thus became less attractive. Palm oil required shipment through Belawan, because only this port posssessed the storage facilities and infrastructure to accommodate large liquid bulk carriers. While the far southern regions supported extensive tracts of oil palm, most exports were fed to Belawan for export; in Asahan by rail and Labuhan Batu by bulk lighters up the coast.

Just as long distance foreland links, in part a result of Belawan's focus upon highervalue, foreign-owned estate products, helped solidify the port's position atop the regional

\footnotetext{
${ }^{99}$ During the boom years from 1923 to 1928 and the Depression years from 1929 to 1933 , vessel size averaged 3808 registered tons and 2808 registered tons respectively. During the same two time periods the average number of annual vessel calls increased from 114 to 502 respectively. Data was compiled from numerous colonial statistical sources.

100 Pelzer, Planter and Peasant, pp. 64-65.

101 Statistiek var de Scheepvaart in Nederlandsch Indië (Batavia, 1937). The thirteen foreign steamship companies refer to companies operating vessels with foreign connections out of Belawan, but do not include the Straits Settlements.

102 G. Allen and A. Donnithorne, Western Enterprise in Indonesia (London: Allen and Unwin, 1962), p. 222.
} 
port hierarchy, the nature of the export products from small ports, in turn, assisted in their viability. The majority of exports at the lower-order ports were lower-value native products controlled by Chinese middlemen with connections in the Straits Settlements. Although by 1938, both Kwaloe and Bandar Chilapah no longer engaged in trans-Straits trade, other smaller ports remained quite resilient based upon product type. Just as port facilities in Belawan became segregated according to product, so did the regional port system. ${ }^{103}$

Despite official policy discrimination against smaller ports, many lower-order ports met the needs of smaller-scale producers. The DSM concentrated on the transport of highervalue and larger-volume estate exports to Belawan, whereas the lower-value, bulkier native products were viewed as being less profitable. Native products then continued to be exported primarily through the smaller ports despite the imposition of higher port tariffs in the mid-1920s. ${ }^{104}$ To recover the cost overruns of constructing the new ocean-harbor facilities in Belawan, port duties were raised to levels exceeding similar charges at smaller ports. Although only a small percentage of its total export trade was comprised of native product exports, Belawan competed with smaller ports for the trans-Straits trade, and exporters began using smaller ports to avoid paying higher duties. The government swiftly imposed similar duties at the smaller ports so as not to give them a cost advantage over Belawan in the trans-Straits trade. 105

The case of Tanjung Pura illustrates the relationship between the nature of exports and Belawan's capture of port foreland and hinterland. Changes in foreland situation brought about by the ascendency of Singapore over Penang as the major international transshipment port of the region affected the status of Tanjung Pura. Belawan's capture of Tanjung Pura's trans-Straits traffic in the early 1920s was inevitable because of close road and rail connections, but was also aided by the fact that Tanjung Pura's trade was exclusively with Penang, a port now supporting fewer and fewer international trade connections. The trade captured by Belawan was primarily estate exports, not native products which Tanjung Pura continued to export to Penang.

\section{Conclusions}

The distinguishing characteristic of both the Pioneer and Florescence Eras of plantation development in colonial North Sumatra is the scale of investment and production. Because transport is one link in the chain of production, each era is characterized by a different portcentered transport system morphology. Just as production technologies of the industrialized world were replicated in the resource frontier, matching transport technologies were required in North Sumatra better to articulate transport between the producing and consuming region. In a sense, the spatial configuration of port hinterlands, forelands, and degree of port facility development reflected the scale of foreign investment and production, whether it be Western corporate or smaller-scale Chinese.

103 The percentage of total native exports for the higher-order ports of Belawan ( 8 percent), Tanjung Balai (40 percent) and Labuhan Bilek (45 percent) was considerably less than that of the lower-order ports of Tanjung Tiram (88 percent), Kwaloe (95 percent) and Tanjung Bringin ( 99 percent). Jaarverslag van De Handelsvereeniging te Medan (Medan: Varekamp and Company, 1923), p. 111.

104 Although not reflected in port statistics, it is important to point out that natively produced rubber in the far southern regions experienced difficult times during the rubber restriction scheme of the middle 1930s. The harvest licenses were purchased by large, Medan-based rubber traders and some exports shifted to Belawan. See G.L. Tichelman, Memorie van Overgave en Aanvullende Nota van de Onderafdeling Laboen Batu (ARA, 1934 ), p. 59. 105 De Waard, De Oostkust (9), p. 298. 
During the Pioneer Era, Western-owned plantations were small scale, as was the trade in native products by Chinese merchants. Individual port hinterlands were not extensive; port facilities were not well developed; and, because of the low volumes of trade, port forelands were short in distance. Belawan's hinterland and port facilities were the best developed, but its forelands were equal to those of other regional ports as the volume of production did not warrant long-distance oceanic connections.

Production linkages, of which transport is a part, became more direct during the Florescence Era. North Sumatra no longer was a peripheral resource frontier, supporting an indirect and thus inefficient port-centered transport system. Fully integrated into a single foreign-controlled production system, corporate interests required focused investments to improve production efficiency. Belawan thus dramatically expanded its hinterland to include much of the province, and supported a modern ocean harbor, which in turn allowed for an expansion of port forelands to include direct overseas connections by increasingly larger vessels. The spatial configuration of port hinterlands, forelands, and port facility infrastructure of the smaller regional ports remained relatively static because, despite the dramatic increase in smallholder rubber, the scale of production of native producers did not require substantial changes in the provisioning of transport by Chinese traders during the Florescence Era. When dissecting the single regional transport system, one discovers two separate spatial systems. These smaller ports, however, eventually lost their trade volume as both hinterland and foreland connections became increasingly concentrated in Belawan. Tanjung Balai, a port that continued to service both small- and large-scale producers alike, survived the "weeding out" process as short distance foreland connections with Singapore remained.

This functional interplay between structural shifts in industrial world economies and the transformation of port-centered transport systems in North Sumatra is in fact materializing in a new form today. The focus of foreign investment on higher-value, export-oriented manufacturing in West Java and other dominant economic regions of Southeast Asia have left North Sumatra as an economically lagging region, largely dependent upon the export of lower-value plantation and other primary products. Few vessels call at Belawan, as one port on a multi-port itinerary so common during the post-independence period, because both cargo volume and value are relatively low. In response, Belawan's forelands have once again become constricted and are, for the most part, limited to a container feeder service to Singapore. Belawan's container transport hinterland is all but complete, save for the smallscale fish and fresh vegetable export trade to Singapore from Tanjung Balai. As was the case during the colonial period, economic impulses from port forelands greatly influence the spatial configuration of North Sumatra's port-centered transport development. 
